\title{
A MYRTLE WARBLER NESTING RECORD FOR REGINA
}

\author{
by Frank H. Brazier, Regina
}

We in Regina are well acquainted with the Myrtle Warbler (Dendroica coronata) which comes through in large numbers in spring and fall migration. However, the Myrtle normally nests in the coniferous forest of central Saskatchewan, the nearest locality being at Madge Lake, 160 miles northeast of Regina.

At noon on July 8, 1965 I was walking in the shade of tall spruce trees, perhaps 35 feet high on the average, which border our Legislative Grounds along Albert Street in Regina. Thus strolling I was amazed to hear the sharp "check, check, check" of a Myrtle Warbler and to find a female of that species flitting restlessly among the spruce. She was still flitting about when I returned after lunch, and my first thought was that she must be a very late migrant. The next day she was still there and this time I watched her for quite a long time; I was astonished to see that she was not feeding but gathering insects in her bill and that when she had a good billful she would disappear, shortly to reappear with her bill empty. She was feeding young!

I enlisted the help of Elmer Fox and Margaret Belcher to ensure some sort of continuity for the watch. Elmer discovered what appeared to be the nest site, some 30 feet up near the top of a spruce, on the evening of July 9 th, but because of its inaccessibility we never did actually see the nest. The female warbler continued to visit this site with food throughout the day of July 10th. It rained heavily during the night of July 10-11, and when Margaret visited the scene at 9:00 a.m. July 11th the focus of the Myrtle's feeding forays had shifted to a nearby elm where Margaret saw a large young bird being fed. We abandoned the watch at noon, July 12 th, but not before I found that the birds had moved to another tree about 100 feet north of the nest site, where feeding continued, and where I was able on one occasion to see the young bird and satisfy myself that is was a Brown-headed Cowbird (Molothrus ater).
During all this time we had neither sight nor sound of a male Myrtle Warbler. However, when I discussed the matter with Fred Lahrman of the Saskatchewan Museum of Natural History, he volunteered the information that he had heard a male Myrtle Warbler singing in that immediate area on June 10 or 11 , but had simply dismissed it as a late migrant. It seems the male Myrtles are active in the task of raising the young so probably this Myrtle came to an untimely end.

This spring was generally late and cold, and the early summer wet and relatively cool. We shall probably never know what induced a pair of Myrtle Warblers to breed in Regina this spring, but it may have had something to do with the unusually cool spring and the large number of tall spruce trees in the Legislative Grounds, both factors producing an approximation of their normal breeding habitat. Delayed migration may have found them in such an area at a time when it was normal for them to take up breeding territory. Whatever it was, it resulted in a first breeding record for Regina, in the heart of the plains, a long way fromi coniferous forest.

Editor's Note: The Myrtle Warbler, as stated, is normally a resident of the northern coniferous forest, breeding from the southern limits of this forest north into the subarctic, but not usually nesting within the Transition Life Zone to the south. There are a few other extra-limital breeding records for Saskatchewan. At least one Myrtle Warbler pair nested in 1965 in the Moose Mountains in southeastern Saskatchewan where a party consisting of Ross Lein, Richard Sanderson, and Spencer Sealy undertook an ornithological survey. They noted a singing male apparently on territory in spruce trees near their cabin on May 10 . On May 30 Robert R. Taylor found a female near the spruce trees building a nest in the crotch of a birch tree about 20 feet above the ground; the outside structure of the nest was completed but the nest was 
never lined and was not used. At least one singing male was found in the same area as late as June 14, and on the next day a female was seen near their cabin. The coniferous trees in the Moose Mountain Provincial Park have all been introduced; although the area has a northern aspect because of its altitude, there are no native conifers, the major tree species being Aspen. In this same season, E. Manley Callin reports a sporadically singing male Myrtle Warbler was noted in the planted evergreens on the Fort San grounds (in the Qu'Appelle River valley) up to June 27. He suspects that it was nesting, inasmuch as this is the area in which he reported finding a nest on June 17, 1956, and the area in which he believed a pair to have nested in 1955 (Blue Jay, $14: 88)$. Miss Joyce Gunn reported, in the same brief note, a pair of Myrtle Warblers nesting in an introduced spruce tree at Spirit Lake; two young warblers and a cowbird nest-mate still being present on July 20, 1956. Fort San is 45 miles east-northeast of Regina, Spirit Lake, about 125 miles northeast of Regina. These extralimital breeding records are of considerable interest, showing a tendency for this species to nest occasionally in appropriate habitat where available outside of the usual geographic limits of its range.

\section{ASSOCIATION OF A PINTAIL DRAKE AND A MALLARD PAIR \\ by W. Harvey Beck, Regina}

A male Pintail (Anas acuta) was observed by me on four occasions in close association with a pair of Mallards (Anas platyrhynchos), on Morgan Creek, approximately eight miles southwest of Killdeer, Saskatchewan. The first observation was made at 8:00 p.m. on May 15, 1965 when the trio was flushed. The three birds flew up together, circled, and landed as a group a short distance upstream. The following morning, May 16 , between $6: 25$ a.m. and $6: 35$ a.m., the birds were observed feeding on the creek in the same location. No aggressive behaviour was noted between the males of the two species, and the hen demonstrated no preference for either male. When the trio was flushed, they again flew un together with both males remaining close to the female, circled, and landed as a group 100 yards upstream. As I left the area. they returned to the spot from which they had been flushed, and resumed feeding. Later the same day (4:00 p.m. and $4: 30$ p.m.) the birds were flushed twice and repeated the morning's performance each time.

Sibley (1957) has pointed out that there are a number of isolating mechanisms which curtail or prevent interbreeding between species. In ducks, the time of pair formation, male plumage characters, and nuptial display or "courtship" serve as isolating mechanisms. Hybridization, however, is proof that interbreeding does occur. Interspecific hybrids among ducks are well known (see Cockrum, 1952; Childs, 1952; Sibley, 1957; Dzubin, 1959; Martz, 1964). A number of Mallard x Pintail hybrids have been reported. In addition, the Saskatchewan Museum of Natural History has two male Mallard x Pintail hybrids from Saskatchewan in its collection: SMNH 4161 was collected near Imperial, SMNH 6315 at Horizon. Dzubin (1959) reported an association between a drake Pintail and a Mallard pair, and Nero (1959) reported an association between a male Green-winged Teal and a Mallard pair. Both authors suggest that associations of this type may provide an explanation for the production of hybrids in the wild.

\section{LITERATURE CITED}

Childs, H. E., Jr. 1952. Hybrid between a Shoveller and a Blue-winged Teal. Condor, $54: 67-68$

Cockrum, E. L. 1952. A check-list and bibliography of hybrid ducks in North America north of Mexico. Wilson Bull., 64:140-159.

Dzubin, A. 1959. A Pintail drake-Mallard pair association. Blue Jay, $17: 53-54$.

Martz, G. F. 1964. Mixed trio of a Shoveller drake and Blue-winged Teal pair. Wilson Bull., 76 :291-292.

Nero. R. W. 1959. Green-winged Teal - Mallard pair association. Blue Jay, $17: 54$.

Sibley. C. G. 1957. The evolutionary and taxonomic significance of sexual dimorphism and hybridization in birds. Condor, $59: 166-191$. 